\title{
Organization of Ionotropic Glutamate Receptors at Dendrodendritic Synapses in the Rat Olfactory Bulb
}

\author{
Marco Sassoè-Pognetto ${ }^{1,2}$ and Ole P. Ottersen ${ }^{2}$ \\ ${ }^{1}$ Department of Anatomy, Pharmacology and Forensic Medicine, University of Turin, I-10126 Turin, Italy, and 2Department \\ of Anatomy, Institute of Basic Medical Sciences, University of Oslo, Blindern, N-0317 Oslo, Norway
}

Dendrodendritic synapses between mitral (or tufted) and granule cells of the olfactory bulb play a major role in the processes of odor discrimination and olfactory learning. Release of glutamate at these synapses activates postsynaptic receptors on the dendritic spines of granule cells, as well as presynaptic NMDA receptors in the mitral cell membrane. However, immunocytochemical studies have failed to demonstrate the presence of ionotropic glutamate receptors in granule cell dendrites. By using a postembedding immunogold procedure, we describe here the precise organization of neurotransmitter receptors at dendrodendritic synapses. We show that there is a selective localization of glutamate and GABA receptors at asymmetric and symmetric synaptic junctions, respectively. In addition, we demonstrate that NMDA and AMPA receptors are clustered at postsynaptic specializations on granule cell spines and that they are extensively colocalized. Conversely, glutamate receptors do not appear to be concentrated in clusters on mitral cell dendrites, suggesting that the presynaptic effects of glutamate are mediated by a small complement of extrasynaptic receptors. By analyzing the subsynaptic distribution of the NR1 and GluR2/3 subunits, we show that they are distributed along the entire extent of the postsynaptic specialization, indicating that both NMDA and AMPA receptors are available for dendrodendritic signaling between mitral and granule cells. These results indicate that the principles recently found to underlie the organization of glutamate receptors at axospinous synapses also apply to dendrodendritic synapses.

Key words: dendrodendritic synapse; olfactory bulb; NMDA receptors; AMPA receptors; GABA receptors; subsynaptic distribution; postembedding immunogold
The reciprocal synapses between mitral (and tufted) and granule cells of the olfactory bulb were the first dendrodendritic synapses described in the CNS (Hirata, 1964; Rall et al., 1966). These synapses are located in the external plexiform layer (EPL) in which they constitute the large majority of the synaptic junctions and consist of an asymmetric mitral-to-granule synapse directly adjacent to a symmetric granule-to-mitral synapse (Price and Powell, 1970a,b). The dendrodendritic circuit forms the basis for feedback inhibition of the mitral cells and provides a mechanism for lateral inhibition that may be relevant for odor discrimination and olfactory learning (Yokoi et al., 1995; Brennan and Keverne, 1997).

Because of their unique properties and their importance for olfactory processing, dendrodendritic synapses have been studied intensively (for review, see Shepherd and Greer, 1998). These studies have demonstrated that mitral cells release glutamate and excite granule cell dendrites (Trombley and Shepherd, 1992; Wellis and Kauer, 1994), which in turn mediate GABAergic inhibition back onto the mitral cells (Nicoll, 1971; Nowycky et al., 1981a; Jahr and Nicoll, 1982; Wellis and Kauer, 1993). Recent electrophysiological investigations have revealed unexpected properties of dendrodendritic synapses, including a dependence

\footnotetext{
Received Oct. 21, 1999; revised Dec. 10, 1999; accepted Dec. 13, 1999.

This work was supported by the Italian Ministry for University and Research, the Norwegian Research Council, and Letten F. Saugstad's Fund. We thank Drs. Robert J. Wenthold and Jean-Marc Fritschy for their generous gift of the antibodies; B. Riber and K. M. Gujord for excellent technical assistance; and Dr. Yutaka Takumi and Bill Janssen for many helpful discussions.

Correspondence should be addressed to Dr. Marco Sassoè-Pognetto, Department of Anatomy, Pharmacology and Forensic Medicine, Corso Massimo d'Azeglio 52, I-10126 Turin, Italy. E-mail: marco.sassoe@unito.it.

Copyright (C) 2000 Society for Neuroscience 0270-6474/00/202192-10\$15.00/0
}

on NMDA, rather than AMPA, receptors for the activation of granule cells (Isaacson and Strowbridge, 1998; Schoppa et al., 1998) and a self-excitation of mitral cell dendrites, similarly dependent on NMDA receptors (Aroniadou-Anderjaska et al., 1999; Isaacson, 1999). Based on these observations, one would hypothesize that NMDA receptors are located presynaptically as well as postsynaptically at dendrodendritic synapses, but this remains to be shown by anatomical techniques. Likewise, it is not known whether NMDA and AMPA receptors differ in their distance from the presynaptic active zones, which could explain why AMPA receptors are less effective than NMDA receptors at eliciting GABA release from granule cells. The specialized arrangement of reciprocal synapses also suggests that NMDA receptors could be located close to the GABA release sites on granule cell dendrites and that entry of calcium through these receptors could contribute to trigger the release of GABA (see Discussion in Isaacson and Strowbridge, 1998; Schoppa et al., 1998).

Although much attention has been focused on the physiological properties of dendrodendritic interactions, little is known on the organization of neurotransmitter receptors at reciprocal synapses. The subsynaptic localization of receptors is now regarded as a major determinant of the behavior of synaptic connections (Luján et al., 1997; Ottersen and Landsend, 1997; Nusser, 1999) and is particularly relevant in the case of reciprocal junctions. Surprisingly, recent immunocytochemical investigations have failed to demonstrate glutamate receptors on the dendritic spines of granule cells, although there is evidence that both ionotropic and metabotropic glutamate receptors may be located presynaptically in mitral cell dendrites (van den Pol, 1995; Montague and Greer, 1999). In the present study, we used a sensitive, high-resolution 
immunogold procedure (Matsubara et al., 1996) to characterize the distribution of ionotropic glutamate receptors at dendrodendritic synapses. To our knowledge, this is the first analysis of the precise distribution of glutamate receptors at a dendrodendritic synapse.

\section{MATERIALS AND METHODS}

Tissue preparation. Adult (3 months old) Wistar rats were deeply anesthetized by an intraperitoneal injection of sodium pentobarbital $(50$ $\mathrm{mg} / \mathrm{kg}$ ) and perfused through the left ventricle with $2 \%$ ice-cold dextran (molecular weight 70,000) in 0.1 m sodium phosphate buffer (PB), pH 7.4, for $15 \mathrm{sec}$, and then by $4 \%$ formaldehyde (freshly depolymerized from paraformaldehyde) in $0.2 \mathrm{M}$ acetate buffer, $\mathrm{pH} 6.0$, followed by $4 \%$ formaldehyde in $0.2 \mathrm{M}$ sodium carbonate buffer, $\mathrm{pH} 10.5$, room temperature $(50 \mathrm{ml} / \mathrm{min}$ for $20 \mathrm{~min})$. This "pH-shift" protocol has been found previously to provide optimal detection of the antigenic epitopes combined with good ultrastructural preservation (Nagelhus et al., 1998). Specimens from the main olfactory bulb were rinsed in PB with $4 \%$ glucose $\left(4^{\circ} \mathrm{C}\right.$, overnight $)$, cryoprotected in increasing concentrations of glycerol $(10,20$, and $30 \%$ in PB), and rapidly frozen in liquid propane in a cryofixation unit (KF80; Reichert, Vienna, Austria). They were then freeze-substituted with methanol and embedded in Lowicryl HM20 (Lowi, Waldkraiburg, Germany), as described previously (Hjelle et al., 1994; Chaudhry et al., 1995).

Antibodies. The antibodies against glutamate receptors have been raised in rabbits against synthetic peptides corresponding to the C-terminal domain of the following subunits: NR1, GluR1, GluR2, GluR2/3, and GluR4. They were obtained from Chemicon (Temecula, CA) or were kind gifts of Dr. Robert J. Wenthold (National Institutes of

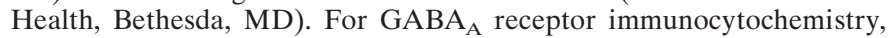
we used monoclonal antibody bd-17, which recognizes the $\beta 2$ and $\beta 3$ subunits (Haring et al., 1985). This antibody was a kind gift of Dr. Jean-Marc Fritschy (Institute of Pharmacology, University of Zurich, Zurich, Switzerland). All of these antibodies have been thoroughly characterized and widely used for immunocytochemical localization of glutamate and GABA receptors with light and electron microscopic immunocytochemistry (Petralia and Wenthold, 1992; Petralia et al., 1994, 1997; Fritschy and Mohler, 1995; Nusser and Somogyi, 1997; Takumi et al., 1999b).

Postembedding immunocytochemistry. Ultrathin sections were collected on uncoated nickel grids (500 mesh) and processed for immunogold cytochemistry as described by Matsubara et al. (1996). Briefly, the sections were etched with a saturated solution of $\mathrm{NaOH}$ in absolute ethanol for 2-3 sec, rinsed with double-distilled water, and incubated sequentially in the following solutions (at room temperature): (1) $0.1 \%$ sodium borohydride and $50 \mathrm{~mm}$ glycine in Tris buffer $(5 \mathrm{~mm})$ containing $0.1-0.9 \% \mathrm{NaCl}$ and $0.1 \%$ Triton X-100 (TBNT) (10 min); (2) 2\% human serum albumin (HSA) in TBNT (10 min); (3) antibodies to NMDA,

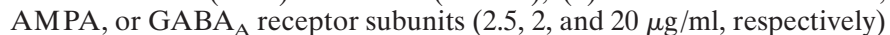
in TBNT containing 2\% HSA (overnight); (4) TBNT (several rinses) and $2 \%$ HSA in TBNT (10 min); and (5) goat anti-rabbit or goat anti-mouse Fab fragments coupled to $10 \mathrm{~nm}$ colloidal gold particles (GFAR10 and GFAM10; British BioCell International, Cardiff, UK), diluted 1:20 in TBNT with $2 \%$ HSA and $0.05 \%$ polyethyleneglycol $(2 \mathrm{hr})$. The grids were then rinsed several times in double-distilled water, counterstained with uranyl acetate and lead citrate, and examined in a Philips EM 410 electron microscope.

Double immunogold labeling. Two methods were used to determine whether the NR1 subunit of NMDA receptors and the GluR2/3 subunit of AMPA receptors occur at the same synapses on the dendritic spines of granule cells. (1) Double labeling was performed by using formaldehyde vapor to avoid interference between the two sequential labeling procedures (Wang and Larsson, 1985; Ottersen et al., 1992). The first immunolabeling (NR1) was performed as described using a secondary antibody coupled to $10 \mathrm{~nm}$ gold particles. The sections were then exposed to formaldehyde vapor for $1 \mathrm{hr}$ at $80^{\circ} \mathrm{C}$. This treatment was followed by the second immunolabeling in which the localization of the other antigen (GluR2/3) was revealed by $20 \mathrm{~nm}$ gold particles (GAR20; British BioCell International). The other possible combination (GluR2/3 labeling followed by NR1 labeling) was also performed. Double labelings were always accompanied by control experiments in which the incubation in the primary antibody was omitted from the second immunolabeling procedure. In these cases, only the immunoreactivity specific for the first immunolabeling procedure was detected. (2) Pairs of consecutive sec- tions collected on single-slot grids were labeled for either NR1 or GluR2/3 as described above.

Quantitative analysis. The proportion of synapses immunopositive for NR1 or GluR2/3 was assessed directly in the electron microscope by analyzing randomly selected grid squares. Every asymmetric synapse was recorded, and the number of gold particles was calculated. A synapse was considered immunopositive when it contained at least two gold particles in the synaptic cleft or postsynaptic density (Baude et al., 1995; Rubio and Wenthold, 1997; Bernard and Bolam, 1998). Colocalization of NMDA and AMPA receptors was assessed in photographic montages taken from paired consecutive sections labeled for either NR1 or GluR2/3 (see also Results).

The distribution of labeling along the axis perpendicular to the postsynaptic membrane (radial axis) was determined by examining micrographs of transversely cut synaptic profiles, with well defined presynaptic and postsynaptic membranes. The original micrographs $(105.000 \times)$ were digitized on an Epson GT-7000 Photo scanner, and the distance between the center of gold particles and the midpoint of the postsynaptic membrane was measured with NIH Scion Image software. To define the tangential distribution of labeling along the postsynaptic specialization, the distance of each gold particle from the center of the synaptic profile was measured and normalized. The data, expressed as percentage of gold particles, were grouped in five bins along the mediolateral extent of the postsynaptic specialization.

Nomenclature. No obvious difference has been found between the dendrites of mitral cells and those of tufted cells in conventional electron microscopic studies. Unless specified, in the present study the term mitral cell dendrite refers to dendrites of both types of principal neuron.

\section{RESULTS}

\section{Synaptic organization of the EPL}

In the EPL, the secondary (basal) dendrites of mitral cells establish reciprocal synapses with the dendritic spines (gemmules) of granule cells (Rall et al., 1966; Price and Powell, 1970b). These reciprocal pairs constitute over $80 \%$ of all synaptic junctions in this layer (Shepherd and Greer, 1998). Examples of the reciprocal synapses are shown in Figure 1 . Figure $1 A$ shows a reciprocal synaptic junction that was labeled with an antiserum against the NR1 subunit of the NMDA receptor. The mitral-to-granule synapse is asymmetric (Colonnier, 1968) and is strongly labeled. Conversely, the granule-to-mitral synapse is symmetric and is unlabeled. Figure $1 B$ shows another reciprocal synapse, labeled with an antibody against two $\mathrm{GABA}_{\mathrm{A}}$ receptor subunits $(\beta 2$ and $\beta 3)$. Gold particles are precisely located over the symmetric synapse and are absent from the asymmetric synapse. Hence, these results are consistent with electrophysiological studies, which indicate that the mitral-to-granule synapses are glutamatergic and the granule-to-mitral ones are GABAergic (for review, see Trombley and Shepherd, 1993).

Although there is evidence that all synapses between mitral and granule cells occur in pairs (Price and Powell, 1970d; Jackowski et al., 1978; Woolf et al., 1991), demonstration of the reciprocal arrangement often requires reconstruction of serial sections. Even in single sections, however, dendrodendritic synapses can usually be identified according to morphological criteria (Price and Powell, 1970b). It should be emphasized that mitral cells can also form reciprocal dendrodendritic synapses with a different type of GABAergic interneuron, although such synapses probably occur at a much lower density than those with granule cells (Toida et al., 1996). Therefore, although in the present study we will refer to dendrodendritic synapses as those occurring between mitral and granule cells, the possibility exists that at least some of them involve a different type of interneuron.

Another type of asymmetric synapse in the EPL is the one formed by centrifugal afferents with the gemmules of granule cells (Price and Powell, 1970c). The axon terminals involved in these junctions are usually filled with vesicles and appear much 

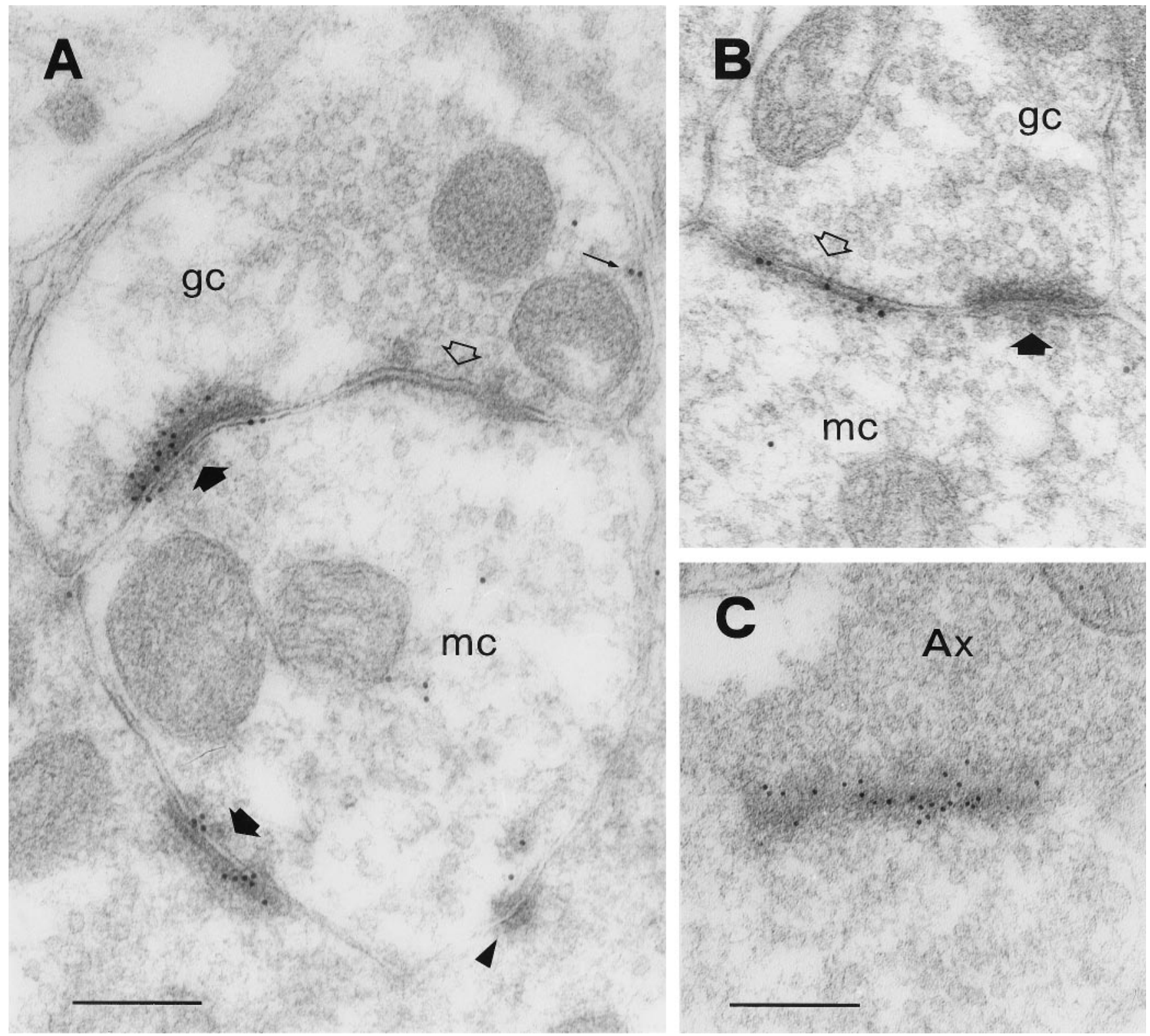

Figure 1. Synaptic organization of the EPL. $A$ shows a reciprocal dendrodendritic synapse between a mitral cell $(m c)$ and a granule cell $(g c)$, labeled with an antibody against the NR1 subunit of the NMDA receptor. There is strong immunolabeling over the asymmetric junction (thick filled arrow) but no labeling at the symmetric one (open arrow). Gold particles are distributed along the postsynaptic density, although some appear to be more closely associated with the presynaptic membrane. Another asymmetric synapse with a different granule cell spine is also labeled (bottom thick filled arrow). A few gold particles are sparse in the cytoplasm of the mitral cell dendrite, and two might be associated with the extrasynaptic membrane of the granule cell (small arrow). The triangle indicates a punctum adherens. $B$ shows another reciprocal synapse that was labeled with an antibody against the $\beta 2 / 3$ subunit of the $\mathrm{GABA}_{\mathrm{A}}$ receptor. Immunolabeling occurs only at the symmetric junction (open arrow). $C$ shows an axodendritic synapse that was labeled for GluR2/3. This synapse is cut obliquely and displays a particularly strong immunolabeling. The axon terminal $(A x)$ is filled with vesicles and appears much darker than mitral cell dendrites (compare with $A$ and $B$ ). Axodendritic synapses occur at a low density in the EPL. Scale bars: $A, 200 \mathrm{~nm} ; B, C, 240 \mathrm{~nm}$.

darker than the mitral cell dendrites (Fig. 1C). Therefore, axodendritic synapses can be recognized by their morphology. In the present study, axodendritic synapses were observed only occasionally and were found to be labeled with the antibodies against both NMDA (data not shown) and AMPA receptors (Fig. 1C). Thus, it is likely that at least some of the axodendritic synapses in the EPL are glutamatergic.

\section{Localization of NMDA receptors at dendrodendritic synapses}

The distribution of NMDA receptors in the EPL was investigated with an antiserum against the NR1 subunit, the obligatory sub- unit for all functional NMDA receptors (Moriyoshi et al., 1991; Kutsuwada et al., 1992; Meguro et al., 1992; Monyer et al., 1992) (for review, see Nakanishi, 1992). Most of the immunoparticles representing the NR1 subunit were associated with asymmetric synapses and were usually not present at symmetric junctions (Fig. 1A). As noted in the previous section, the large majority of the labeled synapses were dendrodendritic and were between mitral and granule cells (Fig. 2). If we assume as criterion for defining an immunopositive synapse the presence of at least two gold particles within the postsynaptic specialization (Baude et al., 1995; Rubio and Wenthold, 1997; Bernard and Bolam, 1998), 

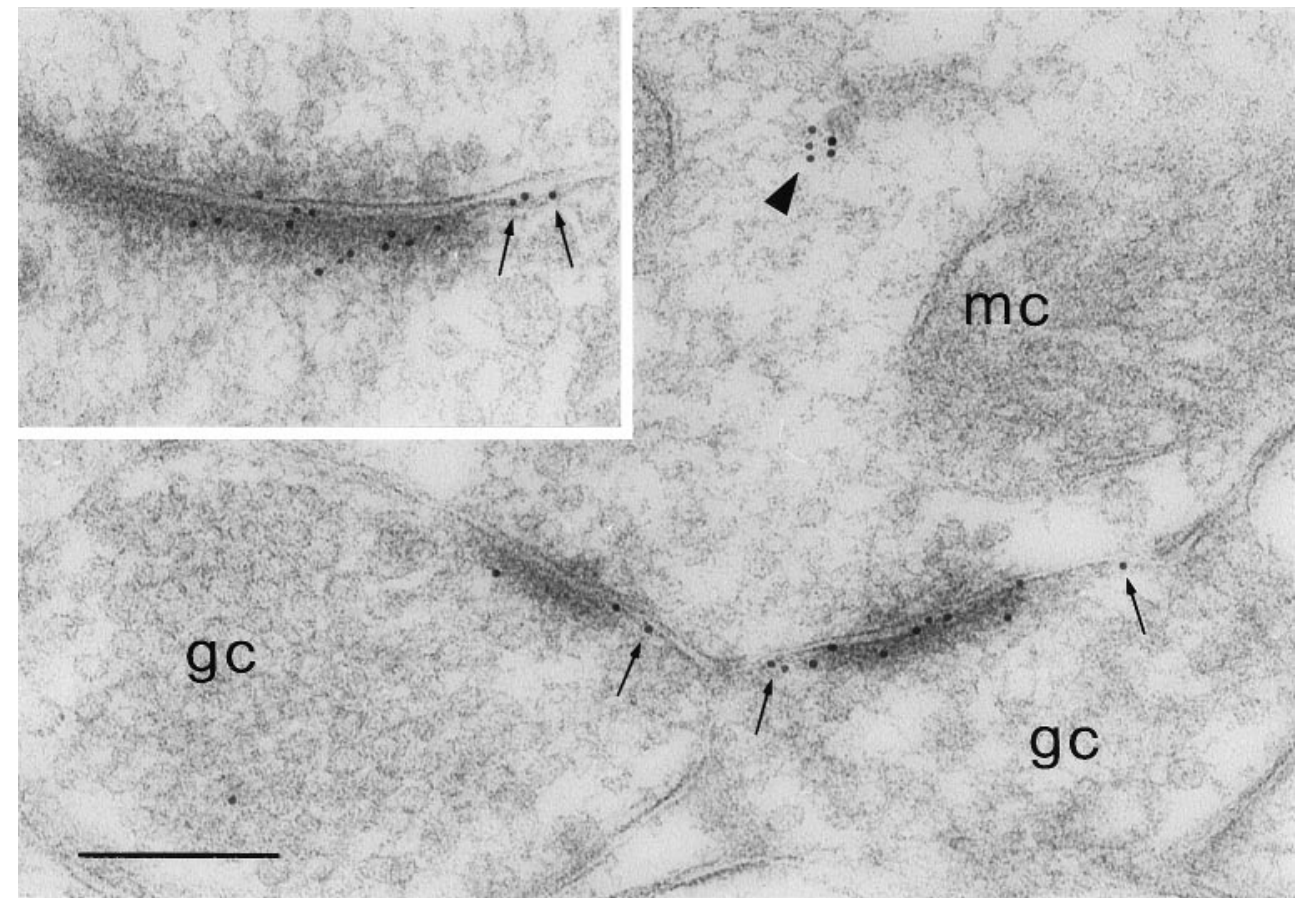

Figure 2. Immunoreactivity for NR1 at dendrodendritic synapses. A mitral cell dendrite $(m c)$ makes NR1-positive synapses with two granule cell spines $(g c)$. Small arrows indicate gold particles that are associated with the extrasynaptic membrane. Note the presence of a cluster of gold particles in the cytoplasm of the mitral cell dendrite (triangle). Inset, Other example of a labeled dendrodendritic synapse. Gold particles are distributed along the postsynaptic density, although some are located extrasynaptically (small arrows). Scale bar, $240 \mathrm{~nm}$.
$89.9 \%$ of the asymmetric synapses in our sample (152 of 169) were labeled. This is probably an underestimate, considering that we used single, rather than serial, sections to assess each synapse (Nusser et al., 1998). In addition, only eight synapses (4.7\%) displayed no gold particles at all. We thus conclude that the large majority, and possibly all of the mitral-to-granule synapses, express NMDA receptors. This conclusion is in line with results from the hippocampus in which close to $100 \%$ of the Schaffercommissural synapses in the CA1 stratum radiatum were immunopositive for the NMDA receptor (Takumi et al., 1999b).

Outside of synaptic specializations, gold particles were found at a much lower density. Some particles were located in the cytoplasm of mitral cell dendrites in which they often formed small clusters. Only a few particles appeared to be associated with extrasynaptic membrane domains (Fig. 2).

There were cases in which gold particles seemed to be closely associated with the presynaptic membrane (Fig. 1A). To determine whether NMDA receptors can be expressed presynaptically, we analyzed the distribution of gold particles along the axis perpendicular to the postsynaptic membrane. A total of 548 particles were analyzed in a sample of 71 synapses. The labeling pattern was consistent with a predominantly postsynaptic localization of NMDA receptors (Fig. $3 A$ ). In fact, particle density was highest within the postsynaptic membrane and exhibited a smaller peak at $18 \mathrm{~nm}$ inside the granule cell dendrite, but there was no peak on the presynaptic side. Tangentially, gold particles (331 particles in 42 synapses) were distributed along the entire extent of the postsynaptic specialization, although they were more concentrated at the center (Fig. 4A).

\section{Localization of AMPA receptors at dendrodendritic synapses}

Native AMPA receptors are believed to be hetero-oligomeric complexes assembled from four different subunits, named GluR1GluR4 (Hollmann et al., 1989; Boulter et al., 1990; Keinänen et al., 1990; Nakanishi et al., 1990) (for review, see Hollmann and Heinemann, 1994). All of the cloned AMPA receptor subunits are expressed in the olfactory bulb (Keinänen et al., 1990; Petralia and Wenthold, 1992; Molnar et al., 1993; Martin et al., 1993; Giustetto et al., 1997; Montague and Greer, 1999), but their precise localization within the olfactory synaptic circuits has not been determined. To investigate the cellular and subcellular localization of AMPA receptors in the EPL, we used four different antibodies that recognize the following subunits: GluR1, GluR2, GluR2/3, and GluR4. All of the antibodies labeled the asymmetric synapses established by mitral cell dendrites with granule cell gemmules (Fig. 5A-C; GluR1 not shown). The granule-to-mitral synapses were generally unlabeled (Fig. $6 A$ ), although occasionally gold particles were found over symmetric synaptic specializations (data not shown). Outside of synaptic specializations, there was only poor labeling in the cytoplasm of mitral and granule cell dendrites. Only the antibody against GluR $2 / 3$ produced a strong and consistent labeling of asymmetric synapses (Fig. 6A,B), which allowed for quantitative evaluation of the immunoreactivity. In a sample of 155 synapses, $125(80.6 \%)$ contained at least two gold particles, and only $10(6.4 \%)$ were completely devoid of particles. Because it cannot be excluded that even immunonegative synapses contain a significant number of receptors (Nusser et al., 1998), these results indicate that the large majority of the asymmetric synapses in the EPL express AMPA receptors.

To determine what is the exact localization of AMPA receptors with respect to the postsynaptic membrane, we analyzed the distribution of gold particles along the presynaptic-to-postsynaptic axis (404 particles in 58 synapses). The distribution was essentially normal and displayed a single peak just inside the postsynaptic membrane (Fig. $3 B$ ), suggesting that no or very few AMPA receptors are expressed presynaptically. The analysis of the tangential distribution of gold particles (316 particles in 41 synapses) showed that the labeling was relatively even in the central part of the synapse and decreased in intensity at the periphery (Fig. $4 B$ ). It should be noted that the decrease of labeling at the periphery of the postsynaptic specialization may be explained in part by the fact that some of the gold particles signaling peripheral receptors 

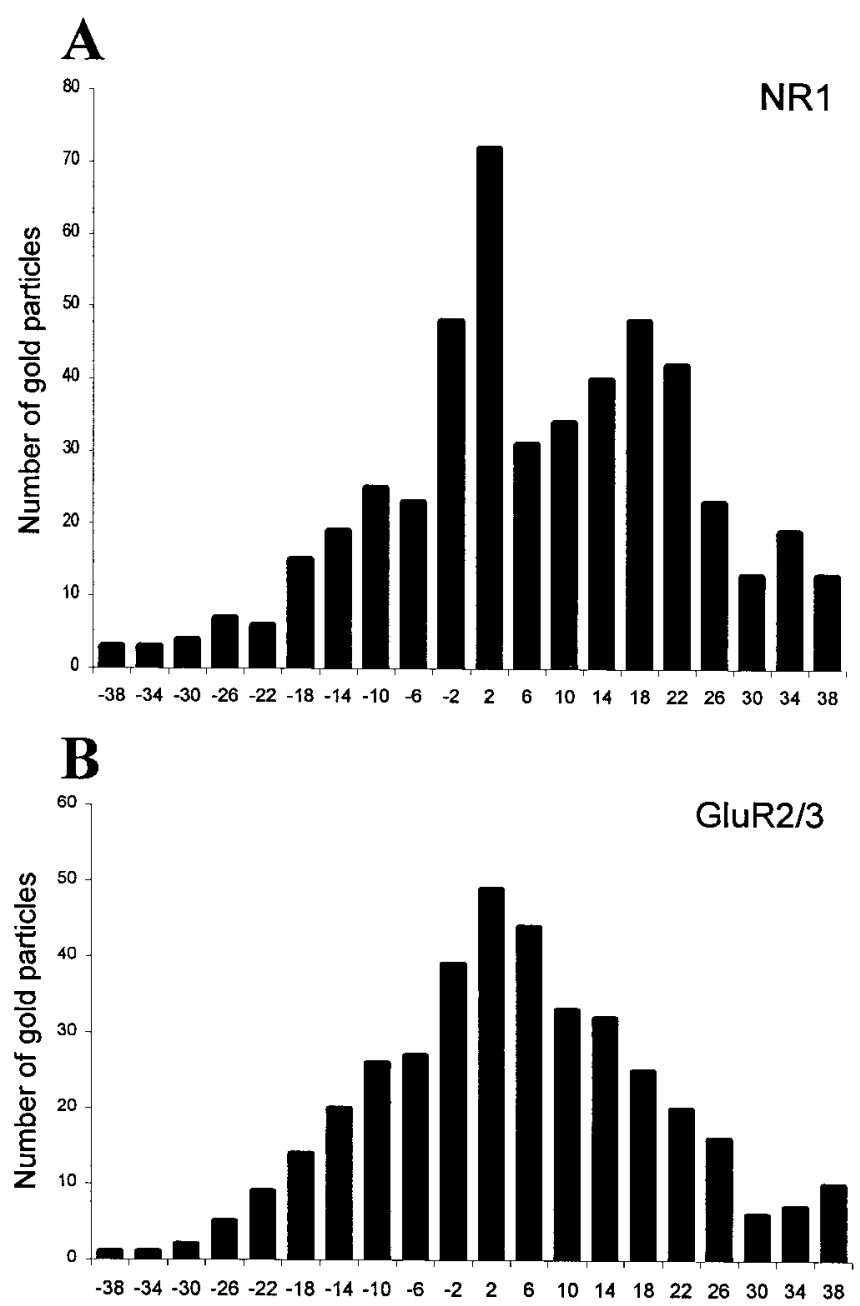

Distance from center of postsynaptic membrane $(\mathrm{nm})$

Figure 3. Histograms showing the radial distribution of gold particles representing NR1 $(A)$ and GluR2/3 $(B)$ at dendrodendritic synapses. The distances between the centers of $10 \mathrm{~nm}$ gold particles and the midpoint of the postsynaptic membrane were grouped into bins $4 \mathrm{~nm}$ wide (bin centers indicated). Negative values correspond to bins located presynaptically. The data were pooled from $71(A)$ and $58(B)$ synapses. For both NR1 and GluR2/3, labeling is concentrated at the cytoplasmic face of the postsynaptic membrane. The histogram of NR1 shows a second peak at 18 $\mathrm{nm}$ on the postsynaptic side.

will end up lateral to the postsynaptic density and thus fail to be recorded (Landsend et al., 1997).

\section{Colocalization of NMDA and AMPA receptors}

The high proportion of NR1- and GluR2/3-positive synapses observed in the EPL suggested that NMDA and AMPA receptors are extensively colocalized at dendrodendritic synapses. This was confirmed by double-labeling experiments, in which gold particles of different size (10 and $20 \mathrm{~nm}$, respectively) were used for simultaneous visualization of the NR1 and GluR2/3 subunits on the same sections (Fig. $7 A-D$ ). This analysis also suggested that the two receptor types are intermingled rather than expressed in distinct subdomains of the postsynaptic specialization.

The use of $20 \mathrm{~nm}$ gold particles caused a significant reduction in the labeling intensity, and a larger proportion of immunonegative synapses was detected already by visual inspection. To assess quantitatively the colocalization between NMDA and AMPA
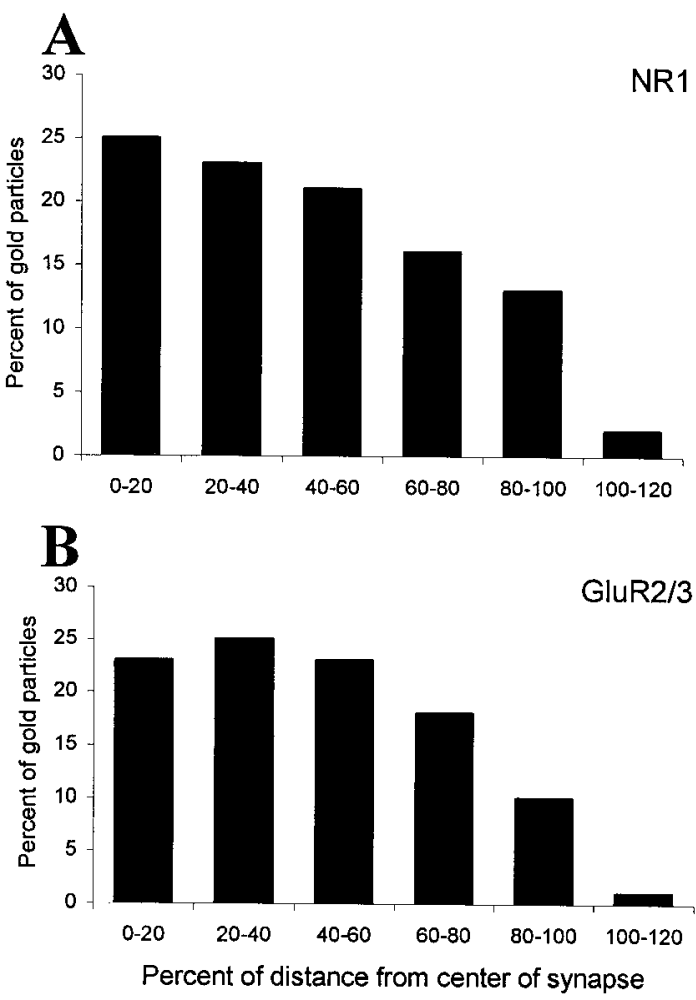

Figure 4. Histograms showing the tangential distribution of gold particles representing NR1 $(A)$ and GluR2/3 $(B)$ at dendrodendritic synapses. Each bin represents one-fifth of the diameter of the postsynaptic specialization, with zero defined as the center. The data were pooled from 42 $(A)$ and $41(B)$ synapses. Only synaptic profiles with a diameter of at least $200 \mathrm{~nm}$ were included in this analysis. Immunolabeling occurs along the mediolateral extent of the postsynaptic specialization, with a decrease at the periphery. NR1 appears to be more concentrated at the center of the synapse, whereas the distribution of GluR2/3 is more uniform.

receptors, we therefore analyzed consecutive sections that had been labeled for either NR1 or GluR2/3, using secondary antibodies coupled to $10 \mathrm{~nm}$ gold particles (data not shown). Micrographs were taken from two series of consecutive sections, and a total of 65 synapses were sampled. Only synapses that could be clearly identified in both sections of each pair were included in this analysis. Based on the criterion of more than one gold particle per synapse, NMDA and AMPA receptors were found to be colocalized in 54 synapses $(83 \%)$, whereas eight synapses (12\%) were NR1-positive and GluR2/3-negative, and three (5\%) were NR1-negative and GluR2/3-positive.

\section{DISCUSSION}

In this study, we have characterized the organization of neurotransmitter receptors at dendrodendritic synapses in the olfactory bulb. We have shown that there is a selective localization of glutamate and GABA receptors at asymmetric and symmetric synapses, respectively. This is consistent with the general idea that glutamate released from mitral cell dendrites activates granule cells and that the reciprocal inhibition of mitral cells is mediated by GABA (for review, see Shepherd and Greer, 1998). We have also demonstrated that the NR1 and GluR2/3 subunits of glutamate receptors have a highly compartmentalized distribution on granule cell dendrites and that they are clustered at postsynaptic specializations of asymmetric synapses. In contrast, 

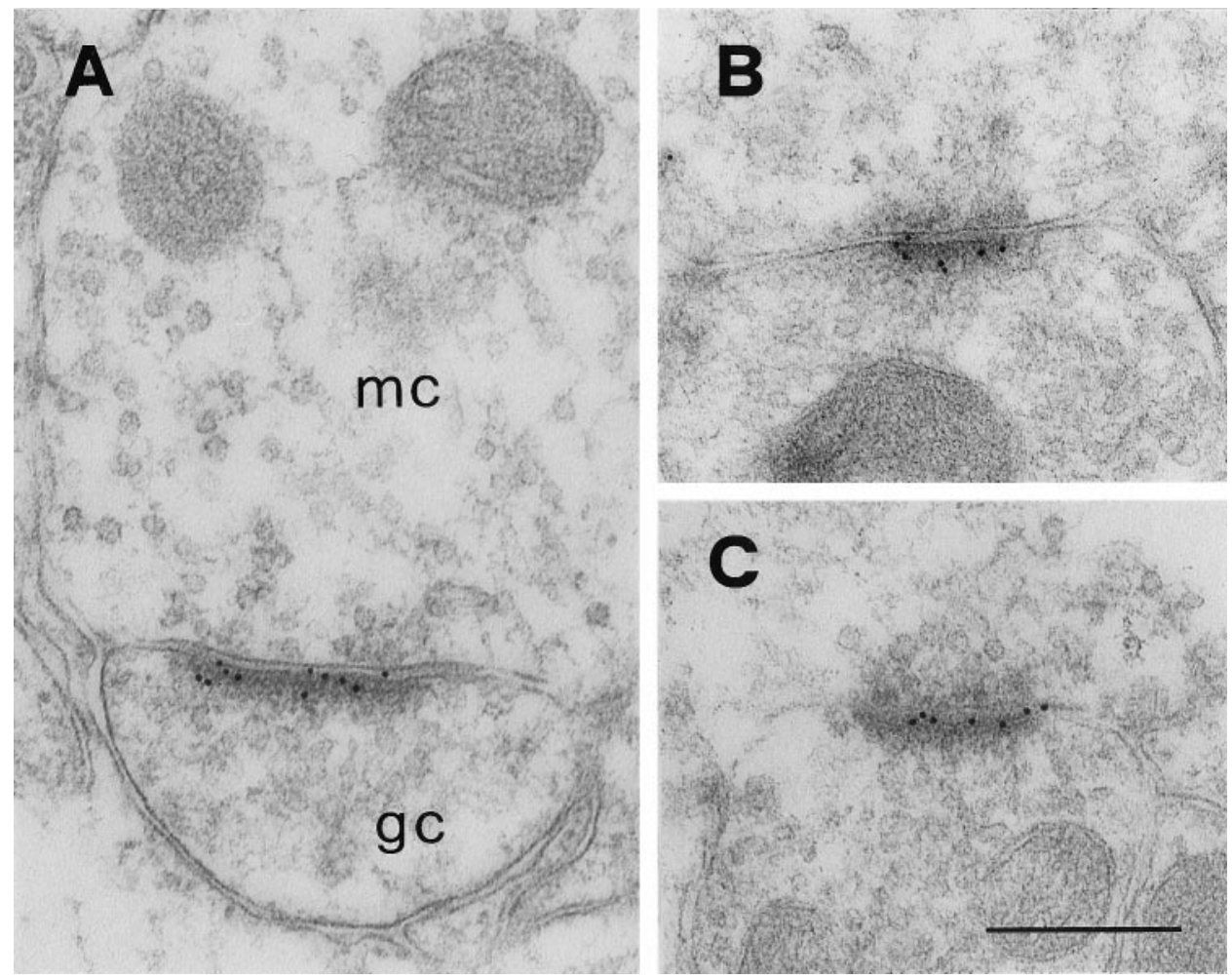

Figure 5. Localization of AMPA receptor subunits at dendrodendritic synapses. All micrographs show asymmetric synapses between presumed mitral $(m c)$ and granule cell $(g c)$ dendrites, labeled with the antibodies against GluR2/3 $(A)$, GluR2 $(B)$, and GluR4 $(C)$. Gold particles are distributed along the entire postsynaptic specialization. Scale bar, $260 \mathrm{~nm}$. glutamate receptors were not expressed at detectable levels on mitral cell dendrites.

\section{Glutamate receptors in granule cells}

Granule cell dendrites in the EPL receive excitatory input from two sources (Price and Powell, 1970b): from the dendrites of mitral cells, which represent the major input to granule cells, and from axon terminals, which account for a more limited number of synapses. In the present study, both types of synapse (dendrodendritic and axodendritic) were found to be labeled by antibodies raised against NMDA and AMPA receptor subunits. The results reported here were based on a sensitive postembedding immunogold technique that allows reliable localization of the epitopes with a high anatomical resolution (Matsubara et al., 1996). It should be noted that previous studies based on preembedding immunocytochemistry failed to demonstrate glutamate receptors in the apical dendrites of granule cells (Montague and Greer, 1999; M. Giustetto and M. Sassoè-Pognetto, unpublished observations). This almost certainly has to do with limitations of the preembedding method, such as poor penetration of the antibodies.

The quantitative analysis in this study revealed that at least 90 and $80 \%$ of dendrodendritic synapses express NMDA and AMPA receptors, respectively, and that colocalization of NR1 and GluR2/3 occurs in a major proportion of dendritic spines. This is consistent with the electrophysiological results of Schoppa et al. (1998), who analyzed miniature EPSCs in granule cells. However, these results leave open the possibility that a small number of dendrodendritic synapses contain NMDA receptors but not AMPA receptors (an even smaller number could be endowed with the complementary receptor profile). A conclusive demonstration of this would require analysis of consecutive sections aimed at determining the receptor content through the postsynaptic area (Nusser et al., 1998; Takumi et al., 1999b).
The subunit composition of glutamate receptors that are expressed by granule cells can only be inferred from previous in situ hybridization analyses. Thus, NMDA receptors are likely to be heteromeric complexes composed of the NR1 subunit combined with NR2A and/or NR2B (Watanabe et al., 1993). All currently known AMPA receptor subunits are expressed by granule cells (Keinänen et al., 1990), and all have been identified in granule cell spines (Fig. 5). In the present study, the antibody against GluR2/3 provided the highest labeling efficacy, perhaps because it recognizes two different subunits. The fact that AMPA receptors in olfactory bulb interneurons have a low calcium permeability (Jardemark et al., 1997) would suggest that the GluR2 subunit is a common constituent of these receptors in granule cells (Hollmann and Heinemann, 1994). Montague and Greer (1999) reported that the GluR1 and GluR2/3 subunits are quite homogeneously distributed in the EPL, whereas the GluR4 subunit is restricted to the most superficial part of this layer. Thus, it is possible that the GluR4 subunit is present in only a subset of dendrodendritic synapses.

It has been shown that dendrodendritic synapses possess unique functional properties, such as a dependence on NMDA receptors rather than AMPA receptors for their activation (Isaacson and Strowbridge, 1998; Schoppa et al., 1998). Here, we have shown that NMDA and AMPA receptors are colocalized at dendrodendritic synapses and that they are distributed along the entire postsynaptic specialization of granule cell spines. The distribution of GluR2/3 was more uniform than that of NR1, the latter showing a more pronounced mediolateral gradient (Fig. 4). Apart from these subtle differences, however, our data suggest that glutamate released from mitral cell dendrites must have an almost equal access to NMDA and AMPA receptors. This implies that differences in the subsynaptic organization of the two glutamate receptor subtypes cannot account for the ineffective- 

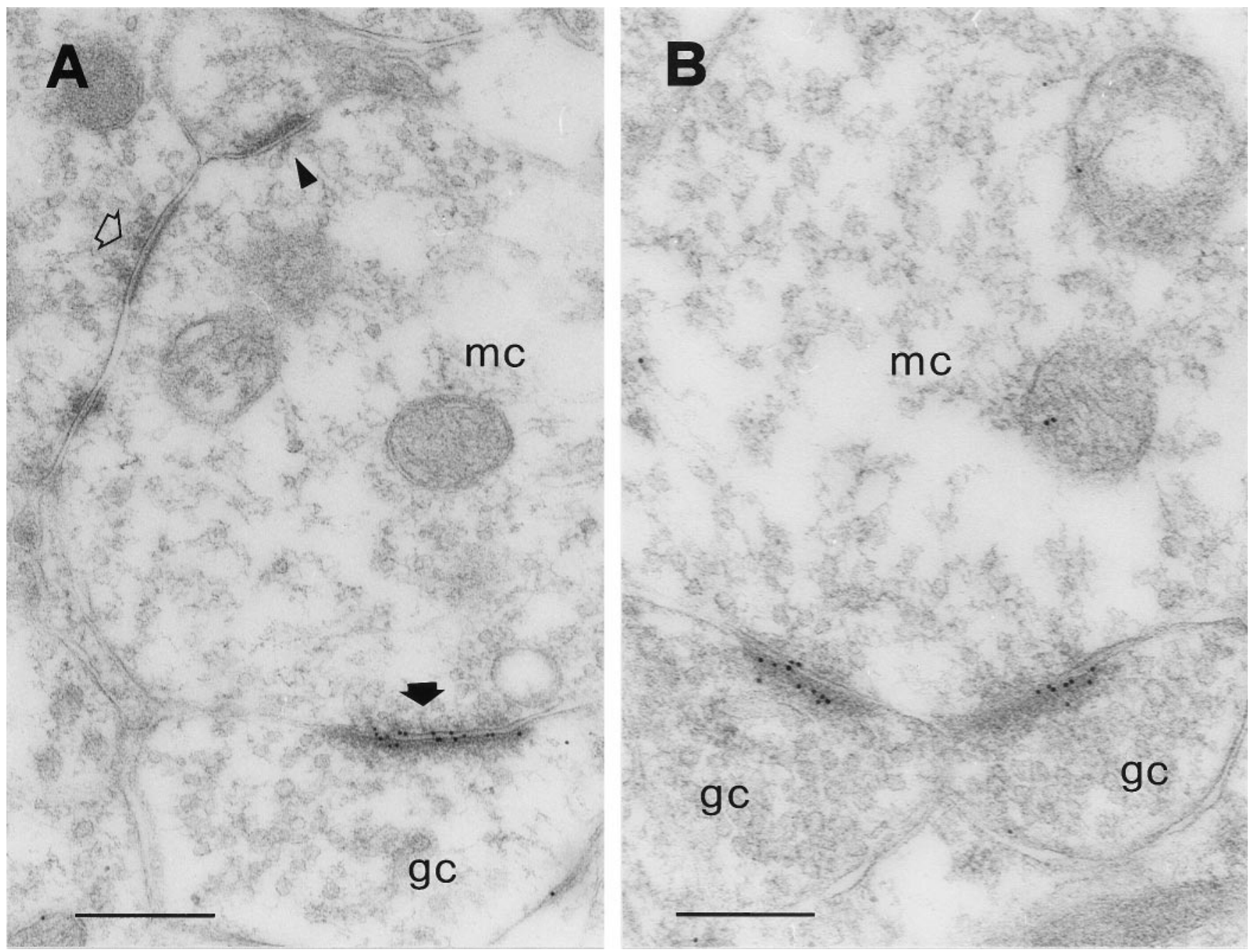

Figure 6. Immunoreactivity for GluR2/3 at dendrodendritic synapses. $A$ shows a mitral cell dendrite $(m c)$ making a GluR2/3-positive synapse ( filled thick arrow) with a granule cell dendrite $(g c)$, as well as a GluR2/3-negative synapse with another dendrite (triangle). A symmetric synapse (open arrow) is not labeled. $B$ shows a mitral cell dendrite $(m c)$ making labeled synapses with two dendritic spines of granule cells $(g c)$. Scale bars: $A, 330 \mathrm{~nm} ; B, 260 \mathrm{~nm}$.

ness of AMPA receptor-mediated responses, which most likely derives from intrinsic properties of the granule cell plasma membrane (Schoppa and Westbrook, 1999).

Our results also have implications for the molecular mechanisms that are responsible for the release of GABA from granule cell spines. The reciprocal arrangement of dendrodendritic synapses has led to the hypothesis that calcium entry through NMDA receptors could trigger directly the release of GABA. However, because neurotransmitter release requires high calcium concentrations within subsynaptic microdomains (Zucker et al., 1999), the selective localization of NMDA receptors at asymmetric synaptic junctions and their exclusion from GABA release sites on the granule cell membrane make this possibility unlikely. This is consistent with the findings of Isaacson and Strowbridge (1998), who demonstrated that voltage-activated calcium channels play a critical role in dendrodendritic recurrent inhibition.

\section{Glutamate receptors in mitral cells}

There is general agreement that mitral cells do not receive excitatory synapses on their basal dendrites in the EPL, and the distribution of glutamate receptors reported here is consistent with this view. Despite this lack of excitatory inputs, dendritic release of glutamate from mitral cells causes self-excitation, which becomes apparent when the inhibitory feedback from granule cells is removed pharmacologically (Nowycky et al., 1981b; Nicoll and Jahr, 1982). Three independent studies have now shown that this recurrent excitation of mitral cell dendrites depends entirely on NMDA receptors (Chen et al., 1998; Aroniadou-Anderjaska et al., 1999; Isaacson, 1999). According to Isaacson (1999), spillover of glutamate can also activate NMDA receptors on neighboring mitral cells. These findings are in apparent contrast with our results, which did not reveal clusters of glutamate receptors on the dendritic membrane of mitral cells. The most obvious explanation for this discrepancy is that the glutamate receptors at this site occur at such low concentrations that they escape detection by the present immunogold approach (see Baude et al., 1995 for an extensive discussion of the immunocytochemical detection of synaptic and nonsynaptic receptors). If this explanation is correct, the recurrent excitation of mitral cells could result from the activation of a small complement of receptors located on the presynaptic dendrite. This would introduce an important concept, that ionotropic glutamate receptors located outside of synaptic specializations may play an important role in cell-to-cell communication. However, because the self-excitation of mitral cells was recorded under conditions that facilitate the activation of NMDA 

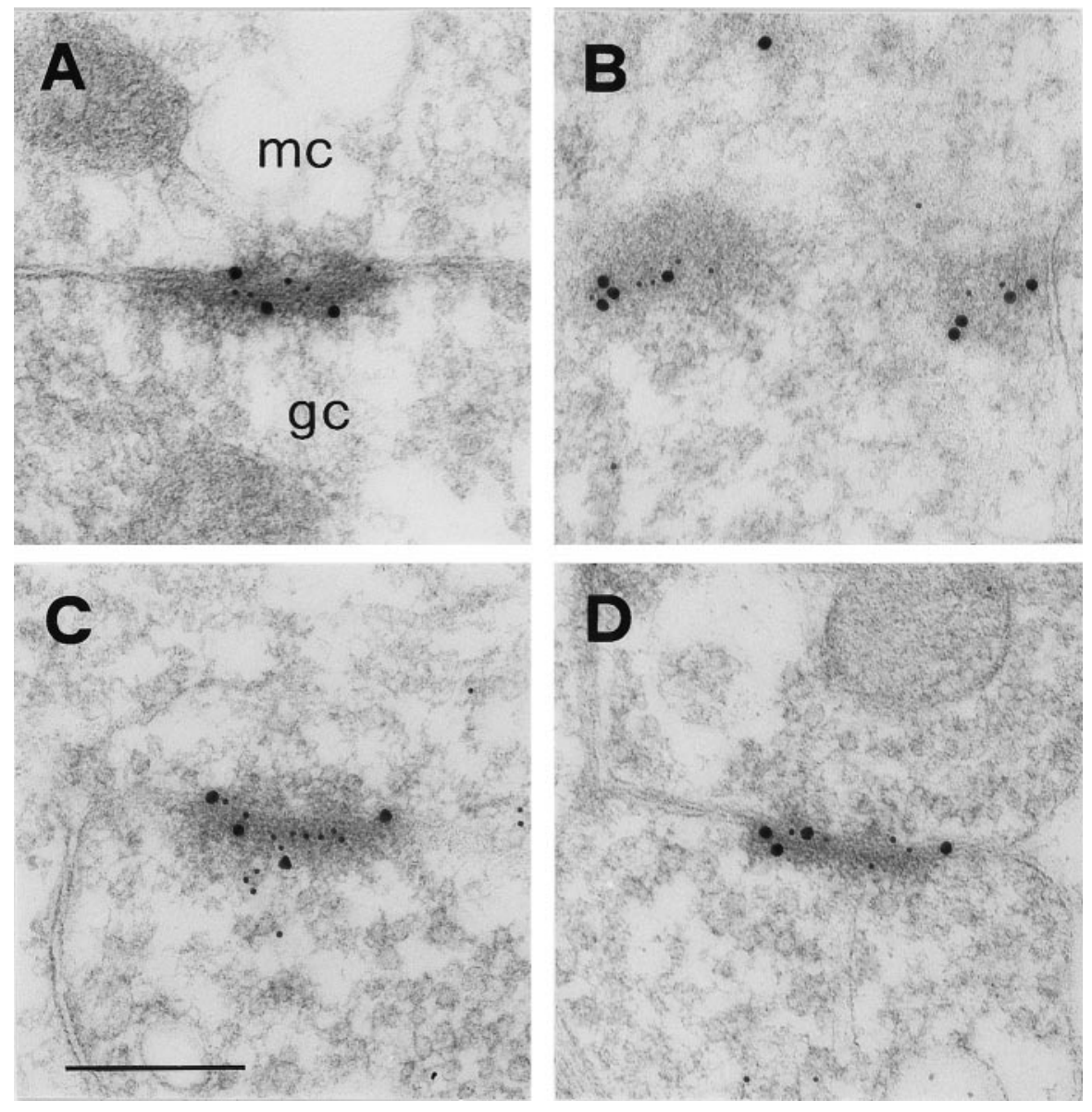

Figure 7. Colocalization of NR1 and GluR2/3 at dendrodendritic synapses. All micrographs show asymmetric synapses between presumed mitral $(m c)$ and granule cell $(g c)$ dendrites. These synapses are cut obliquely, which helps to visualize the relative distribution of the two types of gold particles. NMDA and AMPA receptors appear to be intermingled rather than segregated to different parts of the postsynaptic specialization. Size of gold particles is $10 \mathrm{~nm}$ for NR1 and $20 \mathrm{~nm}$ for GluR2/3 in $A$ and $B$, and the opposite in $C$ and $D$. Scale bar, $260 \mathrm{~nm}$. receptors (e.g., low extracellular $\mathrm{Mg}^{2+}$ ), it is still questionable whether this effect is relevant for synaptic communication in the olfactory bulb.

\section{Subsynaptic organization of glutamate receptors}

The analysis of the radial distribution of gold particles revealed unexpected differences in the postsynaptic organization of the NR1 and GluR2/3 subunits. For GluR2/3, the distribution was essentially similar to that reported by Matsubara et al. (1996) at inner hair cell synapses and showed a single peak on the cytoplasmic side of the postsynaptic membrane. Conversely, the distribution of NR1 revealed a major peak inside the postsynaptic membrane and a second peak positioned $\sim 18 \mathrm{~nm}$ intracellularly. These "twin peaks" could reflect the presence of different NR1 splice variants, bearing different tail lengths. In agreement, the antibody that we used recognizes four splice variants of the NR1 subunit that differ in their C terminus (Wenthold et al., 1992; Hollmann and Heinemann, 1994), and all these isoforms are expressed by granule cells (Laurie et al., 1995). An alternative explanation is that the $\mathrm{C}$-terminal domain has different configurations, which depend on its dynamic interactions with the cytoskeleton. In support of this intriguing possibility, it has been shown that the binding of NR1 to $\alpha$-actinin is displaced by calmodulin (Wyszynski et al., 1997), a process that might explain the calcium-dependent inactivation of NMDA receptors (Ehlers et al., 1996; Zhang et al., 1998; Krupp et al., 1999).

The present results suggest that the principles underlying the organization of ionotropic glutamate receptors might be the same at axospinous and dendrodendritic synapses (Nusser et al., 1994,
1998; Popratiloff et al., 1996; Kharazia and Weinberg, 1997; Landsend et al., 1997; Bernard and Bolam, 1998; He et al., 1998; Wang et al., 1998; Takumi et al., 1999a). The major similarities are as follows. (1) Both NMDA and AMPA receptors are precisely concentrated in the postsynaptic specialization, with few receptors lateral to this. (2) There is a rather even distribution of receptors along the mediolateral extent of the postsynaptic specialization (Figs. 4, 7). Thus, a distinct accumulation of AMPA receptors at the periphery of the synapse may be a feature restricted to select types of synapse with specialized release sites, such as the hair cell synapses in the inner ear (Matsubara et al., 1996). (3) When colocalized, different types of ionotropic receptors are intermingled rather than segregated into distinct subdomains of the postsynaptic density. (4) There is no sizable pool of NMDA and AMPA glutamate receptors in the presynaptic active zone.

\section{REFERENCES}

Aroniadou-Anderjaska V, Ennis M, Shipley MT (1999) Dendrodendritic recurrent excitation in mitral cells of the rat olfactory bulb. J Neurophysiol 82:489-494.

Baude A, Nusser Z, Molnar E, McIlhinney RA, Somogyi P (1995) High-resolution immunogold localization of AMPA type glutamate receptor subunits at synaptic and non-synaptic sites in rat hippocampus. Neuroscience 69:1031-1055.

Bernard V, Bolam JP (1998) Subcellular and subsynaptic distribution of the NR1 subunit of the NMDA receptor in the neostriatum and globus pallidus of the rat: co-localization at synapses with the GluR2/3 subunit of the AMPA receptor. Eur J Neurosci 10:3721-3736.

Boulter J, Hollmann M, O’Shea-Greenfield A, Hartley M, Deneris E, 
Maron C, Heinemann S (1990) Molecular cloning and functional expression of glutamate receptor subunit genes. Science 249:1033-1037.

Brennan PA, Keverne EB (1997) Neural mechanisms of mammalian olfactory learning. Prog Neurobiol 51:457-481.

Chaudhry FA, Lehre KP, van Lookeren CM, Ottersen OP, Danbolt NC, Storm-Mathisen J (1995) Glutamate transporters in glial plasma membranes: highly differentiated localizations revealed by quantitative ultrastructural immunocytochemistry. Neuron 15:711-720.

Chen WR, Ma M, Jia C, Shepherd GM (1998) Roles of action potential propagation, pre- and postsynaptic NMDA receptors in the activation of olfactory dendrodendritic reciprocal synapses. Soc Neurosci Abstr 24:321.

Colonnier M (1968) Synaptic patterns on different cell types in the different laminae of the cat visual cortex. An electron microscope study. Brain Res 9:268-287.

Ehlers MD, Zhang S, Bernhadt JP, Huganir RL (1996) Inactivation of NMDA receptors by direct interaction of calmodulin with the NR1 subunit. Cell 84:745-755.

Fritschy JM, Mohler H (1995) GABA $_{\mathrm{A}^{-}}$-receptor heterogeneity in the adult rat brain: differential regional and cellular distribution of seven major subunits. J Comp Neurol 359:154-194.

Giustetto M, Bovolin P, Fasolo A, Bonino M, Cantino D, SassoèPognetto M (1997) Glutamate receptors in the olfactory bulb synaptic circuitry: heterogeneity and synaptic localization of $N$-methyl-Daspartate receptor subunit 1 and AMPA receptor subunit 1 . Neuroscience 76:787-798.

Haring P, Stahli C, Schoch P, Takacs B, Staehelin T, Mohler H (1985) Monoclonal antibodies reveal structural homogeneity of gammaaminobutyric acid/benzodiazepine receptors in different brain areas. Proc Natl Acad Sci USA 82:4837-4841.

He Y, Janssen WG, Morrison JH (1998) Synaptic coexistence of AMPA and NMDA receptors in the rat hippocampus: a postembedding immunogold study. J Neurosci Res 54:444-449.

Hirata Y (1964) Some observations on the fine structure of synapses in the olfactory bulb of the mouse, with particular reference to the atypical synaptic configurations. Arch Histol Jpn 24:303-317.

Hjelle OP, Chaudhry FA, Ottersen OP (1994) Antisera to glutathione: characterization and immunocytochemical application to the rat cerebellum. Eur J Neurosci 6:793-804.

Hollmann M, Heinemann S (1994) Cloned glutamate receptors. Annu Rev Neurosci 17:31-108.

Hollmann M, O’Shea-Greenfield A, Rogers SW, Heinemann S (1989) Cloning by functional expression of a member of the glutamate receptor family. Nature 342:643-648.

Isaacson JS (1999) Glutamate spillover mediates excitatory transmission in the rat olfactory bulb. Neuron 23:377-384.

Isaacson JS, Strowbridge BW (1998) Olfactory reciprocal synapses: dendritic signaling in the CNS. Neuron 20:749-761.

Jackowski A, Parnavelas JG, Lieberman AR (1978) The reciprocal synapse in the external plexiform layer of the mammalian olfactory bulb. Brain Res 159:17-28.

Jahr CE, Nicoll RA (1982) An intracellular analysis of dendrodendritic inhibition in the turtle in vitro olfactory bulb. J Physiol (Lond) 326:213-234.

Jardemark K, Nilsson M, Muyderman H, Jacobson I (1997) $\mathrm{Ca}^{2+}$ ion permeability properties of $(R, S)$ alpha-amino-3-hydroxy-5-methyl-4isoxazolepropionate (AMPA) receptors in isolated interneurons from the olfactory bulb of the rat. J Neurophysiol 77:702-708.

Keinänen K, Wisden W, Sommer B, Werner P, Herb A, Verdoorn TA, Sakmann B, Seeburg PH (1990) A family of AMPA-selective glutamate receptors. Science 249:556-560.

Kharazia VN, Weinberg RJ (1997) Tangential synaptic distribution of NMDA and AMPA receptors in rat neocortex. Neurosci Lett 238:41-44.

Krupp JJ, Vissel B, Thomas CG, Heinemann SF, Westbrook GL (1999) Interactions of calmodulin and alpha-actinin with the NR1 subunit modulate $\mathrm{Ca}^{2+}$-dependent inactivation of NMDA receptors. J Neurosci 19:1165-1178.

Kutsuwada T, Kashiwabuchi N, Mori H, Sakimura K, Kushiya E, Araki K, Meguro H, Masaki H, Kumanishi T, Arakawa M (1992) Molecular diversity of the NMDA receptor channel. Nature 358:36-41.

Landsend AS, Amiry-Moghaddam M, Matsubara A, Bergersen L, Usami S, Wenthold RJ, Ottersen OP (1997) Differential localization of delta glutamate receptors in the rat cerebellum: coexpression with AMPA receptors in parallel fiber-spine synapses and absence from climbing fiber-spine synapses. J Neurosci 17:834-842.

Laurie DJ, Putzke J, Zieglgansberger W, Seeburg PH, Tolle TR (1995) The distribution of splice variants of the NMDAR1 subunit mRNA in adult rat brain. Mol Brain Res 32:94-108.

Luján R, Roberts JD, Shigemoto R, Ohishi H, Somogyi P (1997) Differential plasma membrane distribution of metabotropic glutamate receptors mGluR1 alpha, mGluR2 and mGluR5, relative to neurotransmitter release sites. J Chem Neuroanat 13:219-241.

Martin LJ, Blackstone CD, Levey AI, Huganir RL, Price DL (1993) AMPA glutamate receptor subunits are differentially distributed in rat brain. Neuroscience 53:327-358.

Matsubara A, Laake JH, Davanger S, Usami S, Ottersen OP (1996) Organization of AMPA receptor subunits at a glutamate synapse: a quantitative immunogold analysis of hair cell synapses in the rat organ of Corti. J Neurosci 16:4457-4467.

Meguro H, Mori H, Araki K, Kushiya E, Kutsuwada T, Yamazaki M, Kumanishi T, Arakawa M, Sakimura K, Mishina M (1992) Functional characterization of a heteromeric NMDA receptor channel expressed from cloned cDNAs. Nature 357:70-74.

Molnar E, Baude A, Richmond SA, Patel PB, Somogyi P, McIlhinney RA (1993) Biochemical and immunocytochemical characterization of antipeptide antibodies to a cloned GluR1 glutamate receptor subunit: cellular and subcellular distribution in the rat forebrain. Neuroscience 53:307-326.

Montague AA, Greer CA (1999) Differential distribution of ionotropic glutamate receptor subunits in the rat olfactory bulb. J Comp Neurol 405:233-246.

Monyer H, Sprengel R, Schoepfer R, Herb A, Higuchi M, Lomeli H, Burnashev N, Sakmann B, Seeburg PH (1992) Heteromeric NMDA receptors: molecular and functional distinction of subtypes. Science 256:1217-1221.

Moriyoshi K, Masu M, Ishii T, Shigemoto R, Mizuno N, Nakanishi S (1991) Molecular cloning and characterization of the rat NMDA receptor. Nature 354:31-37.

Nagelhus EA, Veruki ML, Torp R, Haug FM, Laake JH, Nielsen S, Agre P, Ottersen OP (1998) Aquaporin-4 water channel protein in the rat retina and optic nerve: polarized expression in Müller cells and fibrous astrocytes. J Neurosci 18:2506-2519.

Nakanishi N, Shneider NA, Axel R (1990) A family of glutamate receptor genes: evidence for the formation of heteromultimeric receptors with distinct channel properties. Neuron 5:569-581.

Nakanishi S (1992) Molecular diversity of glutamate receptors and implications for brain function. Science 258:597-603.

Nicoll RA (1971) Pharmacological evidence for GABA as the transmitter in granule cell inhibition in the olfactory bulb. Brain Res $35: 137-149$

Nicoll RA, Jahr CE (1982) Self-excitation of olfactory bulb neurones. Nature 296:441-444.

Nowycky MC, Mori K, Shepherd GM (1981a) GABAergic mechanisms of dendrodendritic synapses in isolated turtle olfactory bulb. J Neurophysiol 46:639-648.

Nowycky MC, Mori K, Shepherd GM (1981b) Blockade of synaptic inhibition reveals long-lasting synaptic excitation in isolated turtle olfactory bulb. J Neurophysiol 46:649-658.

Nusser Z (1999) A new approach to estimate the number, density and variability of receptors at central synapses. Eur J Neurosci 11:745-752.

Nusser Z, Somogyi P (1997) Compartmentalised distribution of $\mathrm{GABA}_{\mathrm{A}}$ and glutamate receptors in relation to transmitter release sites on the surface of cerebellar neurones. Prog Brain Res 114:109-127.

Nusser Z, Mulvihill E, Streit P, Somogyi P (1994) Subsynaptic segregation of metabotropic and ionotropic glutamate receptors as revealed by immunogold localization. Neuroscience 61:421-427.

Nusser Z, Luján R, Laube G, Roberts JD, Molnar E, Somogyi P (1998) Cell type and pathway dependence of synaptic AMPA receptor number and variability in the hippocampus. Neuron 21:545-559.

Ottersen OP, Landsend AS (1997) Organization of glutamate receptors at the synapse. Eur J Neurosci 9:2219-2224.

Ottersen OP, Zhang N, Walberg F (1992) Metabolic compartmentation of glutamate and glutamine: morphological evidence obtained by quantitative immunocytochemistry in rat cerebellum. Neuroscience 46:519-534.

Petralia RS, Wenthold RJ (1992) Light and electron immunocytochemical localization of AMPA-selective glutamate receptors in the rat brain. J Comp Neurol 318:329-354.

Petralia RS, Yokotani N, Wenthold RJ (1994) Light and electron micro- 
scope distribution of the NMDA receptor subunit NMDAR1 in the rat nervous system using a selective anti-peptide antibody. J Neurosci 14:667-696.

Petralia RS, Wang YX, Mayat E, Wenthold RJ (1997) Glutamate receptor subunit 2-selective antibody shows a differential distribution of calcium-impermeable AMPA receptors among populations of neurons. J Comp Neurol 385:456-476.

Popratiloff A, Kharazia VN, Weinberg RJ, Laonipon B, Rustioni A (1996) Glutamate receptors in spinal motoneurons after sciatic nerve transection. Neuroscience 74:953-958.

Price JL, Powell TP (1970a) The morphology of the granule cells of the olfactory bulb. J Cell Sci 7:91-123.

Price JL, Powell TP (1970b) The synaptology of the granule cells of the olfactory bulb. J Cell Sci 7:125-155.

Price JL, Powell TP (1970c) An electron-microscopic study of the termination of the afferent fibres to the olfactory bulb from the cerebral hemisphere. J Cell Sci 7:157-187.

Price JL, Powell TP (1970d) The mitral and short axon cells of the olfactory bulb. J Cell Sci 7:631-651.

Rall W, Shepherd GM, Reese TS, Brightman MW (1966) Dendrodendritic synaptic pathway for inhibition in the olfactory bulb. Exp Neurol 14:44-56.

Rubio ME, Wenthold RJ (1997) Glutamate receptors are selectively targeted to postsynaptic sites in neurons. Neuron 18:939-950.

Schoppa NE, Westbrook GL (1999) Regulation of synaptic timing in the olfactory bulb by an A-type potassium current. Nat Neurosci 2:1106-1113.

Schoppa NE, Kinzie JM, Sahara Y, Segerson TP, Westbrook GL (1998) Dendrodendritic inhibition in the olfactory bulb is driven by NMDA receptors. J Neurosci 18:6790-6802.

Shepherd GM, Greer CA (1998) Olfactory bulb. In: The synaptic organization of the brain (Shepherd GM, ed), pp 159-203. New York: Oxford UP.

Takumi Y, Matsubara A, Rinvik E, Ottersen OP (1999a) The arrangement of glutamate receptors in excitatory synapses. Ann NY Acad Sci 868:474-482.

Takumi Y, Ramirez-Leon V, Laake P, Rinvik E, Ottersen OP (1999b) Different modes of expression of AMPA and NMDA receptors in hippocampal synapses. Nat Neurosci 2:618-624.

Toida K, Kosaka K, Heizmann CW, Kosaka T (1996) Electron microscopic serial-sectioning/reconstruction study of parvalbumin-containing neurons in the external plexiform layer of the rat olfactory bulb. Neuroscience 72:449-466.

Trombley PQ, Shepherd GM (1992) Noradrenergic inhibition of synap- tic transmission between mitral and granule cells in mammalian olfactory bulb cultures. J Neurosci 12:3985-3991.

Trombley PQ, Shepherd GM (1993) Synaptic transmission and modulation in the olfactory bulb. Curr Opin Neurobiol 3:540-547.

van den Pol AN (1995) Presynaptic metabotropic glutamate receptors in adult and developing neurons: autoexcitation in the olfactory bulb. J Comp Neurol 359:253-271.

Wang BL, Larsson LI (1985) Simultaneous demonstration of multiple antigens by indirect immunofluorescence or immunogold staining. Novel light and electron microscopical double and triple staining method employing primary antibodies from the same species. Histochemistry 83:47-56.

Wang YX, Wenthold RJ, Ottersen OP, Petralia RS (1998) Endbulb synapses in the anteroventral cochlear nucleus express a specific subset of AMPA-type glutamate receptor subunits. J Neurosci 18:1148-1160.

Watanabe M, Inoue Y, Sakimura K, Mishina M (1993) Distinct distributions of five $N$-methyl-D-aspartate receptor channel subunit mRNAs in the forebrain. J Comp Neurol 338:377-390.

Wellis DP, Kauer JS (1993) GABA $_{A}$ and glutamate receptor involvement in dendrodendritic synaptic interactions from salamander olfactory bulb. J Physiol (Lond) 469:315-339.

Wellis DP, Kauer JS (1994) GABAergic and glutamatergic synaptic input to identified granule cells in salamander olfactory bulb. J Physiol (Lond) 475:419-430.

Wenthold RJ, Yokotani N, Doi K, Wada K (1992) Immunochemical characterization of the non-NMDA glutamate receptor using subunitspecific antibodies. Evidence for a hetero-oligomeric structure in rat brain. J Biol Chem 267:501-507.

Woolf TB, Shepherd GM, Greer CA (1991) Serial reconstructions of granule cell spines in the mammalian olfactory bulb. Synapse 7:181-192.

Wyszynski M, Lin J, Rao A, Nigh E, Beggs AH, Craig AM, Sheng M (1997) Competitive binding of alpha-actinin and calmodulin to the NMDA receptor. Nature 385:439-442.

Yokoi M, Mori K, Nakanishi S (1995) Refinement of odor molecule tuning by dendrodendritic synaptic inhibition in the olfactory bulb. Proc Natl Acad Sci USA 92:3371-3375.

Zhang S, Ehlers MD, Bernhardt JP, Su CT, Huganir RL (1998) Calmodulin mediates calcium-dependent inactivation of $N$-methyl-Daspartate receptors. Neuron 21:443-453.

Zucker RS, Kullmann DM, Bennet M (1999) Release of neurotransmitters. In: Fundamental neuroscience (Zigmond MJ, Bloom FE, Landis SC, Roberts JL, Squire LR, eds), pp 155-192. San Diego: Academic. 